\title{
A Qualitative Systematic Review of Family Support for a Successful Breastfeeding Experience among Adolescent Mothers
}

\author{
Vetty Priscilla ${ }^{1,2} \mathbb{D}$, Yati Afiyanti ${ }^{1 *}$ (D) , Dyah Juliastuti ${ }^{3}$ (D) \\ ${ }^{1}$ Department of Maternity and Women Health, Faculty of Nursing, Universitas Indonesia, Depok, Indonesia; ${ }^{2}$ Department of \\ Maternity Nursing, Faculty of Nursing, Universitas Andalas, Sumatera Barat, Indonesia; ${ }^{3}$ Nursing Program, Sekolah Tinggi Ilmu \\ Kesehatan IMC Bintaro, Tangerang Selatan, Indonesia
}

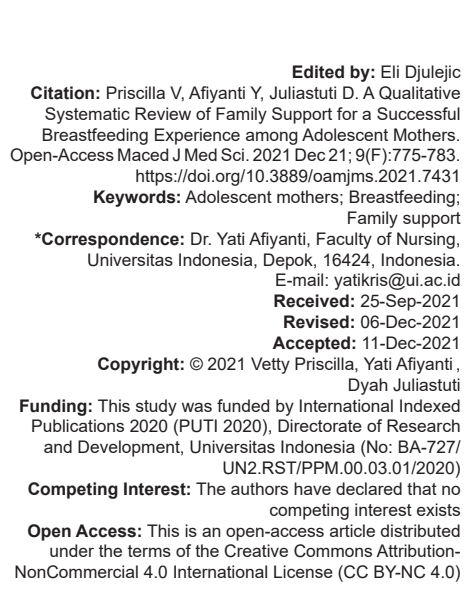

\section{Introduction}

Successful breastfeeding can save many children and mothers globally [1]. More than 820,000 children under five can be protected by breastfeeding, which has provenly prevented an additional 20,000 breast cancer cases each year [2], [3]. Unfortunately, 3 out of 5 newborn babies do not get breast milk in the $1^{\text {st }} \mathrm{h}$ of their life. Mothers who had early breastfeeding initiation were only $42 \%$, and it decreased to $41 \%$ in the $6^{\text {th }}$ month [4]. The success of breastfeeding the baby at the beginning is not followed by the continuity of breastfeeding at a later age [4], [5]. Maternal age is one of the factors causing breastfeeding failure [6], [7], [8].

Teen mothers tend to fail to breastfeed compared to adult mothers [9], [10]. Adolescence is a critical period when self-concept, role achievement, and decision-making abilities are difficult to be achieved as developmental tasks are still in progress [11]. When becoming a mother, teenagers experience a drastic change in their lives as they must adjust to the school responsibilities and the role as a mother [12]. Many teen mothers prefer to stop or not breastfeed their babies [7], mainly when unwanted pregnancies occur [13].

Having a baby at a young age makes teen mothers confused between the role of being a mother and the desire to continue to present themselves in society [8]. Ignorance of the benefits and how to breastfeed are the leading causes of teen mothers failing to complete breastfeed [9], [14]. They usually face obstacles in sharing time between children and other activities such as going back to school and gathering with friends [15]. Moreover, being a mother at a young age made them suffer from a negative stigma from society, including peers [14].

Family support, including from a partner, is one factor that encourages teen mothers to breastfeed their babies [16], [17]. Adolescent mothers who received support from their families took longer breastfeeding than those who did not get the support [18]. To maintain exclusive breastfeeding, $1^{\text {st }}$-time breastfed mothers need support from their families [19]. Many teen mothers still live with their families after giving birth even though they are married. Support from the closest others, especially babies' grandmothers and women's partners, is necessary 
to breastfeed babies [7], [14]. The absence of support from these people impacts the behavior of mothers who do not breastfeed their babies [20]. Spouse support affects adolescent mothers' attitudes toward breastfeeding [1], [8]. The involvement of women's parents in breastfeeding activities is essential for the continuity of breastfeeding [21].

Qualitative research has been widely used in nursing and plays a key role in science development and evidence-based practice. The knowledge of the family or significant others' encouragement for adolescent mothers to successfully breastfeed will enrich family, maternal, and pediatric care services and education. Synthetic findings from recent studies can provide values from the research participants' meaning, experiences, and perspectives and develop new concepts. No systematic research [22] has been conducted to review extensive family support that influences successful breastfeeding among adolescents. This systematic review aims to identify, synthesize, and recognize the results of qualitative research related to family support of successful breastfeeding experienced by adolescent mothers in the global world. The synthesis of derivatives through thematic analysis is carried out by reading the text and coding and generating themes that describe the meaning of the data (Tong et al., 2012). A better understanding of family impact in breastfeeding, particularly among adolescents, may contribute to establishing an effective breastfeeding policy and multidisciplinary health care services using appropriate and acceptable approaches for all women, particularly young mothers.

\section{Methods}

\section{Design}

This study used a systematic review design of qualitative studies following The Enhancing Transparency in Reporting the Synthesis of Qualitative Research developed by Tong (2012) [22]. The process of article selection for this systematic review was carried out according to Nelwati, Abdullah [23] through three stages: (1) developing analytical strategies through inclusion and exclusion criteria as well as article selection, (2) conducting critical and quality assessments as well as data extraction, and (3) performing data aggregation and synthesis of findings.

\section{Strategy}

Potential qualitative articles were chosen through systematic searching and included articles published from 2000 to 2020 using web search engines: PubMed, Sage publications, Cinalh, Proquest, and Sciencedirect. The first author and second author independently used medical subject headings [24] to identify keywords.
The MESH terms used keywords: "breastfeeding" AND "adolescent mothers" OR "teen mothers" AND "family support" OR "grandmother" OR "partner" OR "father" OR "husband" AND "qualitative studies."

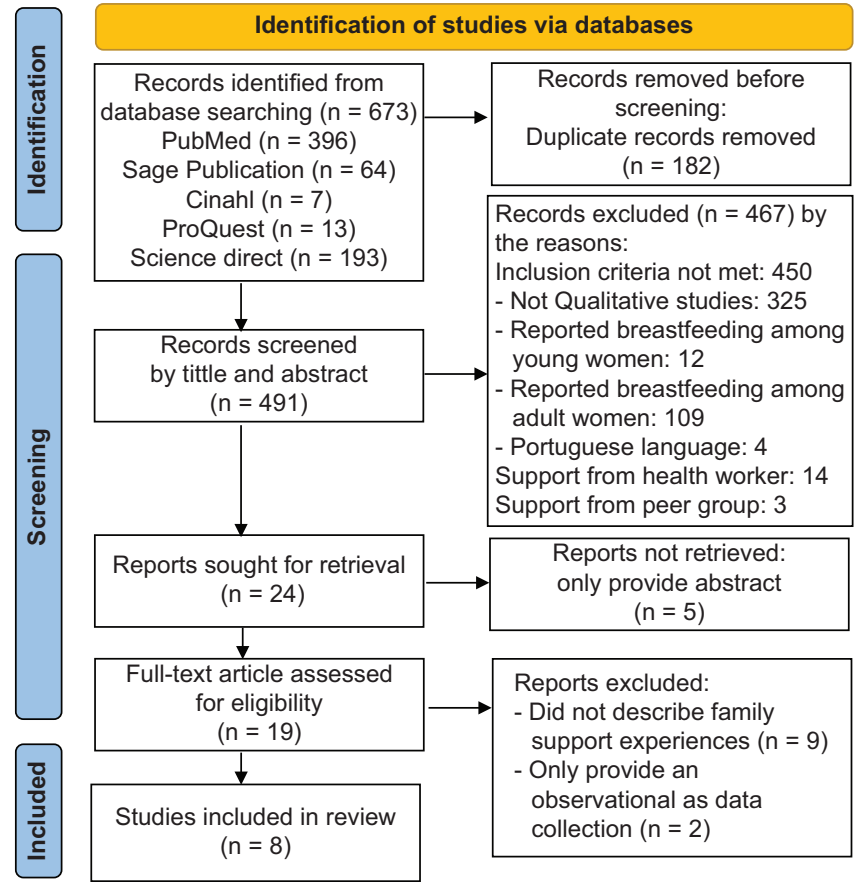

Figure 1: Process of screening and selection reviewed studies

\section{Inclusion and exclusion criteria}

The inclusion criteria of the reviewed articles were full-text qualitative studies in English and published between 2000 and 2020. The reviewed studies must also described family support for breastfeeding among adolescent mothers (age <20-years) who were either pregnant or breastfeeding. The exclusion criteria include data published in from of abstract, letters to editors, comments and editorial as well as articles that included support by non-family members.

\section{Searching}

The literature search results obtained a total of 673 articles from PubMed (396), Sage publications (64), Cinahl (7), Proquest (13), and ScienceDirect (193). The article selection process was carried out independently by the first author. The process was started by reading the title and the abstract of the potential articles. At this stage, 182 duplicate articles and 467 articles, which did not meet the inclusion criteria, were removed. The final eight papers were taken in full-text to be reviewed and stored in EndNote as the author's management tool (Table 1 and Figure 1).

\section{Data extraction and critical appraisal}

The quality of the included reviewed articles was assessed by The Critical Appraisal Skills Program 
Table 1: Summary of the reviewed studies

\begin{tabular}{|c|c|c|c|c|c|c|c|}
\hline \multirow[t]{2}{*}{ No } & \multirow{2}{*}{$\begin{array}{l}\text { Author (year), } \\
\text { country }\end{array}$} & \multirow[t]{2}{*}{ Design } & \multirow[t]{2}{*}{ Sample } & \multirow[t]{2}{*}{ Data collection } & \multicolumn{2}{|l|}{ Research findings } & \multirow[t]{2}{*}{ Successful breastfeeding } \\
\hline & & & & & Source of support & Main outcomes/Themes & \\
\hline S1 & $\begin{array}{l}\text { Acheampong } \\
\text { et al. (2020) } \\
\text { Ghana }\end{array}$ & $\begin{array}{l}\text { A qualitative } \\
\text { exploratory, } \\
\text { descriptive } \\
\text { and contextual } \\
\text { design }\end{array}$ & $\begin{array}{l}30 \text { teenage } \\
\text { mothers }\end{array}$ & $\begin{array}{l}\text { Focus group } \\
\text { discussions (FGD) }\end{array}$ & $\begin{array}{l}\text { Partner, female } \\
\text { parent, and sister }\end{array}$ & $\begin{array}{l}\text { 1. Family history of positive } \\
\text { exclusive breastfeeding } \\
\text { outcomes } \\
\text { 2. Support of intimate partner } \\
\text { 3. Approval of close family } \\
\text { members }\end{array}$ & $\begin{array}{l}\text { Breastfeeding decision and } \\
\text { exclusive breastfeeding } \\
\text { intention }\end{array}$ \\
\hline S2 & $\begin{array}{l}\text { Nuampa } \\
\text { et al. (2018) } \\
\text { Thailand }\end{array}$ & $\begin{array}{l}\text { A qualitative } \\
\text { descriptive }\end{array}$ & $\begin{array}{l}20 \text { adolescent } \\
\text { mothers }\end{array}$ & $\begin{array}{l}\text { Semi structure } \\
\text { in-depth interviews }\end{array}$ & $\begin{array}{l}\text { Grandmother and } \\
\text { female relatives }\end{array}$ & $\begin{array}{l}\text { Family support for } \\
\text { breastfeeding on giving } \\
\text { positive information }\end{array}$ & $\begin{array}{l}\text { Breastfeeding decision and } \\
\text { exclusive breastfeeding in } \\
1 \text { weeks until more than } 3 \\
\text { months }\end{array}$ \\
\hline s3 & $\begin{array}{l}\text { Nesbitt et al. (2012) } \\
\text { Canada }\end{array}$ & $\begin{array}{l}\text { A qualitative } \\
\text { interpretative }\end{array}$ & $\begin{array}{l}16 \text { adolescent } \\
\text { mothers }\end{array}$ & $\begin{array}{l}\text { Semi-structured } \\
\text { interviews }\end{array}$ & $\begin{array}{l}\text { Partner, grandmother, } \\
\text { and sister }\end{array}$ & $\begin{array}{l}\text { The availability and quality of } \\
\text { social support }\end{array}$ & $\begin{array}{l}\text { Breastfeeding decision, } \\
\text { initiation of breastfeeding, } \\
\text { and } \\
\text { breastfeeding duration in } \\
2 \text { days until } 11 \text { months (on } \\
\text { going) }\end{array}$ \\
\hline S4 & $\begin{array}{l}\text { Smith et al. (2012) } \\
\text { USA }\end{array}$ & $\begin{array}{l}\text { A qualitative } \\
\text { prospective } \\
\text { study }\end{array}$ & $\begin{array}{l}5 \text { adolescent } \\
\text { mothers }\end{array}$ & $\begin{array}{l}\text { Semi structure } \\
\text { Interviews }\end{array}$ & $\begin{array}{l}\text { Grandmother and } \\
\text { partner }\end{array}$ & $\begin{array}{l}\text { 1. Breastfeeding } \\
\text { journeys (mixed } \\
\text { breastfeeding messages } \\
\text { and support) } \\
\text { 2. Life journeys (navigating } \\
\text { multiple role) }\end{array}$ & $\begin{array}{l}\text { Breastfeeding decision and } \\
\text { exclusive breastfeeding in } \\
4 \text { days until } 6 \text { months }\end{array}$ \\
\hline S5. & $\begin{array}{l}\text { Nelson and } \\
\text { Sethi (2005) } \\
\text { Canada }\end{array}$ & $\begin{array}{l}\text { A grounded } \\
\text { theory }\end{array}$ & $\begin{array}{l}8 \text { adolescent } \\
\text { mothers }\end{array}$ & Informal interviews & Family, partner & $\begin{array}{l}\text { 1. Decision to breastfeed } \\
\text { 2. Learning to breastfeed } \\
\text { 3. Adjusting to breastfeeding } \\
\text { 4. Ending breastfeeding }\end{array}$ & $\begin{array}{l}\text { Breastfeeding decision and } \\
\text { breastfeeding duration in } 2 \\
\text { months until } 17 \text { months }\end{array}$ \\
\hline S6 & $\begin{array}{l}\text { Wambach and } \\
\text { Cohen (2009) } \\
\text { USA }\end{array}$ & $\begin{array}{l}\text { A qualitative } \\
\text { descriptive }\end{array}$ & $\begin{array}{l}23 \text { teens } \\
\text { breastfeeding } \\
\text { mothers }\end{array}$ & $\begin{array}{l}\text { FGD and } \\
\text { semi-structured } \\
\text { interviews }\end{array}$ & $\begin{array}{l}\text { Grandmother, partner, } \\
\text { other family members }\end{array}$ & $\begin{array}{l}\text { Emotional, instrumental, and } \\
\text { informational Support }\end{array}$ & $\begin{array}{l}\text { Breastfeeding decision and } \\
\text { breastfeeding duration in } \\
\text { one weeks until more than } \\
6 \text { months }\end{array}$ \\
\hline S7 & $\begin{array}{l}\text { Dykes et al. (2003) } \\
\text { United Kingdom }\end{array}$ & $\begin{array}{l}\text { An exploratory } \\
\text { study }\end{array}$ & $\begin{array}{l}20 \text { adolescent } \\
\text { mothers }\end{array}$ & $\begin{array}{l}\text { FGD and in-depth } \\
\text { semi structured } \\
\text { interviews }\end{array}$ & $\begin{array}{l}\text { Grandmother and } \\
\text { partner }\end{array}$ & $\begin{array}{l}\text { Support needs: } \\
\text { Emotional. Esteem, } \\
\text { instrumental, informational, } \\
\text { network }\end{array}$ & $\begin{array}{l}\text { Breastfeeding duration in } \\
4 \text { days until } 6 \text { months }\end{array}$ \\
\hline s8 & $\begin{array}{l}\text { Hannon } \\
\text { et al. (2000) } \\
\text { USA }\end{array}$ & $\begin{array}{l}\text { An ethnographic } \\
\text { study }\end{array}$ & $\begin{array}{l}35 \text { adolescent } \\
\text { mothers }\end{array}$ & $\begin{array}{l}\text { Semi structured } \\
\text { ethnographic } \\
\text { interviews and FGD }\end{array}$ & $\begin{array}{l}\text { Grandmother and } \\
\text { partner }\end{array}$ & $\begin{array}{l}\text { Influential people to } \\
\text { make decision making on } \\
\text { breastfeeding }\end{array}$ & $\begin{array}{l}\text { Breastfeeding decision and } \\
\text { breastfeeding duration in } \\
2 \text { weeks until } 4 \text { weeks }\end{array}$ \\
\hline
\end{tabular}

(CASP) [25]. CASP is one quality assessment tool often used in qualitative research [22]. CASP consists of 10 questions where the first two questions are screening questions that can be answered quickly. The following eight questions are about research design, sampling, research issues, code of ethics, data analysis, results, and value of research data. Each question has answer options: yes, no, and can't tell [25]. The full answers for each article indicate the quality of the writing, which is divided into three levels, namely high (8-10), medium $(5-7)$, and low (1-4) [26]. The quality assessment of the selected articles for this systematic review indicated that seven studies are of high quality, and one is of moderate quality (Table 2 ).

The quality assessment of the included articles was performed by the first author and was confirmed by the second and third author. If different opinions occurred, the results were decided through an open discussion between the authors. All reviewed articles are then grouped for data extraction according to some characteristics of the reviewed studies, such as author or year of article publication, country of origin, qualitative design. The results of data extraction in each reviewed study can be seen in Table 3 .

\section{Data analysis and synthesis}

The collected data were analyzed using a thematic scheme which consisted of three stages: (1) "Line by line coding of textual findings, (2) the development of "descriptive themes" by organizing free codes, and (3) the generation of analitycal themes. These activities yielded new insights and interpretations of the reviewed study phenomenon [22], [27]. The data consistency and reliability were ensured by the second and third authors' debriefing and confirmation on the generated

Table 2: Critical appraisal skills programme (CASP) of the reviewed articles

\begin{tabular}{|c|c|c|c|c|c|c|c|c|}
\hline CASP Items & $\mathrm{S} 1$ & S2 & S3 & S4 & S5 & S6 & S7 & S8 \\
\hline Was there a clear statement of the aims of the research? & + & + & + & + & + & + & + & + \\
\hline Is the qualitative methodology appropriate? & + & + & + & + & + & + & + & + \\
\hline $\begin{array}{l}\text { Was the research design appropriate to address the aims of the } \\
\text { research? }\end{array}$ & + & + & + & + & + & + & ? & + \\
\hline Was the recruitment strategy appropriate to the aims of the research? & + & + & + & + & + & ? & + & ? \\
\hline Was the data collected in a way that addressed the research issues? & + & + & + & + & + & + & + & + \\
\hline $\begin{array}{l}\text { Has the relationship between researcher and participants been } \\
\text { adequately considered? }\end{array}$ & ? & ? & ? & ? & ? & - & - & ? \\
\hline Have ethical issues been taken into consideration? & + & + & + & + & + & + & + & + \\
\hline Was the data analysis sufficient rigorous? & + & + & + & + & + & + & + & + \\
\hline Is there clear statement of finding? & + & + & + & + & + & + & + & + \\
\hline How valuable is the research? & + & + & + & + & + & + & + & + \\
\hline Score/10 & 9 & 9 & 9 & 9 & 9 & 8 & 8 & 8 \\
\hline
\end{tabular}


data and contextualized findings. The authors discussed the emerging themes to reveal their full meaning and themes. Concurrent discussion and consensus among three authors were conducted to solve discrepancy in data analysis and synthesis process.

\section{Results}

\section{Studies characteristics}

The eight reviewed studies represented five countries, namely, Ghana, Thailand, USA, UK, and Canada. The studies were conducted qualitatively using descriptive, exploratory, interpretative, and grounded theory research designs. The numbers of research samples are 5-35 participants who were adolescent mothers aged 14-19 years. The qualitative data were collected through focus group discussions, semi-structured interviews, and in-depth interviews. The family members who supported successful breastfeeding were female parents, spouses, or other family members such as siblings. The success of breastfeeding in adolescent mothers was indicated by the adolescent mothers' intention to breastfeed their babies since pregnancy and their abilities to initiate early breastfeeding, breastfeed exclusively, and maintain breastfeeding continuity from just 2 days to maximum 17 months (Table 1).

Table 3: Common themes among reviewed articles

\begin{tabular}{|c|c|c|c|c|c|c|c|c|}
\hline Themes & S1 & S2 & S3 & S4 & S5 & S6 & S7 & S8 \\
\hline \multicolumn{9}{|l|}{ Appraisal Support } \\
\hline Family members as role model & & & & & & & & $\sqrt{ }$ \\
\hline Encouragement & & & $\sqrt{ }$ & & $\sqrt{ }$ & $\sqrt{ }$ & & $\sqrt{ }$ \\
\hline Self esteem & & & & & & $\sqrt{ }$ & $\sqrt{ }$ & \\
\hline Increasing self-confidence & & & & & $\sqrt{ }$ & & & \\
\hline $\begin{array}{l}\text { Family history of positive breastfeeding } \\
\text { outcomes }\end{array}$ & $\sqrt{ }$ & & $\sqrt{ }$ & $\sqrt{ }$ & & & $\sqrt{ }$ & $\checkmark$ \\
\hline Norms and past experience & & & $\sqrt{ }$ & & & & & $\checkmark$ \\
\hline \multicolumn{9}{|l|}{ Instrumental Support } \\
\hline Help to address constraints & & & & $\checkmark$ & & & $\sqrt{ }$ & $\checkmark$ \\
\hline Manage breastfeeding difficulties & & & $\sqrt{ }$ & & & & & \\
\hline Sharing the load & & & & & & & $\sqrt{ }$ & \\
\hline Financial assistance & $\sqrt{ }$ & & & $\sqrt{ }$ & & & & \\
\hline Continue education & & & & $\sqrt{ }$ & & & $\sqrt{ }$ & \\
\hline Assist and guidance & & & $\checkmark$ & & & $\sqrt{ }$ & & \\
\hline \multicolumn{9}{|l|}{ Emotional Support } \\
\hline Time availability & & & & & & & $\sqrt{ }$ & \\
\hline Approval of breastfeeding & $\sqrt{ }$ & & & & & & & $\sqrt{ }$ \\
\hline $\begin{array}{l}\text { Providing space and time to both mother and } \\
\text { baby }\end{array}$ & & & & $\checkmark$ & & $\checkmark$ & & \\
\hline Caring & & & $\sqrt{ }$ & $\checkmark$ & & & $\sqrt{ }$ & \\
\hline Breastfeeding in public area & & & & $\sqrt{ }$ & & & & \\
\hline Felling obligated in the family & $\sqrt{ }$ & & $\sqrt{ }$ & & & & & \\
\hline \multicolumn{9}{|l|}{ Informational Support } \\
\hline Positive information & $\sqrt{ }$ & $\sqrt{ }$ & & & $\sqrt{ }$ & & $\sqrt{ }$ & $\sqrt{ }$ \\
\hline Good advice & & & & $\sqrt{ }$ & & $\sqrt{ }$ & $\sqrt{ }$ & \\
\hline
\end{tabular}

\section{Methodology quality}

The results of methodological quality analysis using CASP showed that all studies had clear research objectives and accurate qualitative methodologies. The qualitative research design was chosen in accordance with the research objectives, but there was one reviewed study that did not explain why this research design was used [28]. The research objectives that were set in each reviewed study showed what strategy was used to select the research participants. All studies had conducted an ethical test and provided informed consent to participants before the data was taken, but they did not explain the roles of each researcher and participant. The qualitative data found in the studies were analyzed thematically or by content to develop the research findings. Almost all studies illustrate the importance of their research results. The qualitative data generated from the reviewed articles were integrated and synthesized into four types of support given by the families to breastfeeding adolescent mothers, which are emotional, informational, instrumental, and appreciation support, as described in Table 3.

\section{Appraisal support}

Seven reviewed studies indicated that appreciation was the direct support given by the family to adolescent mothers to breastfeed their babies [14], [28], [29], [30], [31], [32], [33]. Breastfeeding experience of family members, the family norm of breastfeeding, and family encouragement for breastfeeding increased teen mothers' self-confidence to breastfeed their babies. Appraisal for the women's efforts in breastfeeding also improved their self-image that they felt better when breastfeeding and decided to continue breastfeeding their babies [33].

Four studies in Ghana, Canada, North Carolina, and North West of England described the positive breastfeeding experienced of the family members motivated the adolescent mother to take the same feeding method [14], [28], [29], [30]. By providing breastmilk for the baby, one study described the baby grew up with love and got close to the mother [29]. The women's mother and sister were the family members who shared positive breastfeeding experiences and became role model for adolescent mothers to choose exclusive breastfeeding to breastfeed for babies [32]. The encouragement to breastfeed is another form of support given by the family, as mentioned by four studies among Canadian, American, and Latina-African-American adolescent mothers [30], [31], [32], [33]. All family members wanted these adolescents to breastfeed their babies [33]. The women's partners supported them to breastfeed their babies and convinced them to perform this feeding method optimally [30]. Besides, women's parents were the primary motivator for the breastfeeding practice [31] as the family norms suggested that every woman had to breastfeed their baby [30]. Moreover, adolescent mothers feel full support from those closest to them [28] [31].

\section{Instrumental support}

The synthesis results of six reviewed articles conducted in Ghana, Canada, the USA, and England 
suggested forms of instrumental breastfeeding support provided by the family, including helping to identify and manage difficulties encountered during breastfeeding, taking over some household chores, providing opportunities to continue education, and assisting or guiding the breastfeeding process [14], [28], [29], [30], [31], [32]. The family helped teen mothers when facing difficulties in breastfeeding, such as improving the breastfeeding position of the mother and baby, so they were in a comfortable position, and the babies were calm [28]. When breastfeeding in public places, the family initiated to cover up the adolescent mother's position that it could not be seen by others and the women would not feel ashamed of breastfeeding their babies [32]. If teen mothers experience breastfeeding problems, the family would come and provided necessary assistance [30]. Sharing responsibilities were also indicated by families, especially couples. Couples are beneficial to mothers when breastfeeding, especially at night [28].

Opportunity to continue education is another crucial support showing by the family in the study by Smith and colleagues (2012) and Dykes and colleagues (2003). The reviewed studies described that women's parents picked up pumped breast milk to campus to give to the baby or brought the baby to campus to be breastfed [14]. The family is a facilitator for teen mothers who can still breastfeed their babies even at school [28]. All the needs of mothers and babies, such as buying baby equipment, are met by the family [14]. Women's partners took part in fulfilling financial needs, so these teen mothers could focus on breastfeeding until the baby is 6 months old [14], [29].

\section{Emotional support}

The synthesis results of five reviewed articles affirmed that breastfeeding approval, a caring family, supporting breastfeeding in public places, and the availability of time and space for mothers and babies are forms of emotional support provided by the family [14], [28], [29], [30], [31]. Families, including partners, usually sit near the teen mothers during breastfeeding and show their care to the adolescent breastfeeding [28]. When breastfeeding in public areas, adolescent mothers always remember the advice of their parents to ensure that the mother's breasts are covered [14]. The female parents look after the baby while the teen mothers go to school [32]. At home, families often facilitate teen mothers and babies to spend time together [14].

Families believe that the bond between mother and baby was formed through the act of breastfeeding [31]. Teen mothers tended to follow the words of female parents, including about the baby's breastfeeding [29]. Teen mothers are free to breastfeed as long as they want [30]. When breastfeeding the baby, partners always prepared beverages or drinks for teen mothers [30].
These young women felt the emotional support shown by partners who always provided breastfeeding assistance to the women whenever they needed them [14].

\section{Informational support}

According to the analysis results of six reviewed articles, information about breastfeeding and advice related to breastfeeding are the informational support provided by the family to the breastfeeding adolescent mothers [14], [28], [29], [31], [32], [34]. The success in breastfeeding was influenced by the information given by the families that breastfeeding is the best feeding method to make babies healthy [32]. Breastfeeding became easy for adolescent mothers because of the information given by their families [33]. The women's mother delivered information about exclusive breastfeeding that these young mothers completed the feeding [29]. These teen mothers relied on positive information from people who had experienced breastfeeding [28]. Women's parents and partners taught and provided some advice related to breastfeed [31]. Furthermore, women's parents suggested breastfeeding when they were not at home [14], [28].

\section{Discussion}

The results of this qualitative systematic review highlight that family significantly contributes to the success of breastfeeding practices among adolescent mothers through their appraisal, instrumental, emotional, and informational support. This study suggests that family as role models, family encouragement, family breastfeeding history, and family norms are related appreciation support from the families to adolescent mothers. Another study in Thailand supports these findings, which explains that adolescent mothers generally become mothers for the $1^{\text {st }}$ time. They lack confidence when interacting with babies and experience various childbearing issues, including breastfeeding difficulties. Thus, most times, these adolescents require full attention from the family [35]. Families and fathers of infants also encourage mothers to breastfeed their babies [36]. Partners are one of the primary motivators of young mothers to breastfeed their babies [37]. These family members' help adolescents make breastfeeding decisions and convince them that they made the right decision by breastfeeding [38]. Further, parents and in-laws share the precious experience of breastfeeding and how it creates a bond with the babies [14].

This present review describes that families usually share their baby's feeding experience with the adolescent mothers, which positively affects the adolescents' confidence and behaviors toward 
breastfeeding. This statement is supported by Tucker and colleagues' study (2011) in North Carolina, America, which describes that family members, who have positive breastfeeding experience influence the mother's decision to initiate early breastfeeding. Unfortunately, some other studies indicate that not all family members have a positive attitude towards breastfeeding. For example, a study in an urban setting in the USA found that the family experience of giving only formula milk to the babies impacted adolescent mothers' attitudes toward breastfeeding as it was perceived not causing problems to the children [17]. This situation can lead to conflict between teen mothers and their families because these young women do not have the power to negotiate, are under pressure, and experience stress in dealing with situations between the desire to breastfeed and the lack of confidence in breastfeeding [39].

Findings of this present study also reported that family assistance to overcome breastfeeding difficulties and problems, complete house chores, solve financial constraints, support educational completion, and accompany and guide the breastfeeding process is essential instrumental encouragement needed and received by the adolescent mothers to maintain the breastfeeding. According to Wambach [10], adolescent breastfeeding mothers lack the initiative to breastfeed and cannot sustain breastfeeding compared to adult breastfeeding mothers. The family who live in the same house, especially female parents and sisters, are always actively involved in motivating and reminding teen mothers to continuously breastfeed their babies [1]. Incongruent with this present review, other studies found partners' role to remind the young mothers about their responsibility to provide breast milk and participate in the process of breastfeeding the baby (such as helping to position the baby for breastfeeding and provide drinks and snacks for the mother during the breastfeeding). When the adolescent does not want to breastfeed their baby, female parents will force her to breastfeed and help her with household duties [19], [40].

In line with this present review, another study describes that during breastfeeding, teen mothers face many barriers between focusing on infant care and returning to school or work [7]. Some teen mothers intend to finish their school and continue studying for higher education, so they can make their parents proud of them. Additionally, these women show their desire to be good a parent for their babies, marry, and take care of their family [14]. To achieve their future goals, teen mothers share their house responsibilities with their female parents, who are happy to support the teen mothers by helping babysit at night and giving pumped breast milk [2].

One of the key findings of this qualitative review is that women's partners play a crucial role in successful breastfeeding. Supporting this finding, the research conducted by Rempel et al. (2017) in Canada illustrates that the form of support provided by partners is sensitive and needs a family teamwork approach to mothers in breastfeeding. The results of this study are also in line with research conducted by Ogbo et al. (2020) suggested that the sensitivity of partners and the ability to solve problems during the breastfeeding process is essential for successful breastfeeding. Partners who are aware of the teen mothers will involve in helping the teen mothers take care of the baby, participate in the breastfeeding process, and do house chores. The role of the partners is as a parent to their child and as a partner/husband in the breastfeeding process [37]. Furthermore, personal support is also provided by the partner, where the partners mitigate not only the physical but also psychological needs of adolescent mothers [15]. Support from partners influences mothers to initiate early breastfeeding and subsequent breastfeeding [5]. Thus, the breastfeeding practice should be decided by both the adolescent mother and her partner [15].

The present review highlights the role of the adolescent mother's partner in providing breastfeeding support and helping to finalize housework. The results of this study are in line with the research conducted by de Lacerda, Lucena de Vasconcelos [15] in Brazil, which describes partners provide support for mothers to breastfeed starting from the antenatal period. Since the mother was pregnant, the partners always motivated the mother to breastfeed. Family, particularly partners, provide financial support to teen mothers because the majority do not work, have low incomes, so they choose to breastfeed their babies to reduce expenses [41]. Women's partners also help with financing health such as care services consulting fees, and medicines, so these teen mothers can focus on taking care and breastfeeding the baby [30]. Most teen mothers are successful in breastfeeding because of the support from their significant families. The families and partners' involvement in the breastfeeding program is required as one of the strategies in promoting breastfeeding, especially among young women.

The process of breastfeeding in adolescent mothers with unwanted pregnancies can cause mental distress due to ignorance of the baby's existence. Due to the stress, in most occurrences, breast milk does not come out and becomes a reason for teen mothers not breastfeeding their babies [6]. The results of this study are in line with research conducted by Afiyanti and Juliastuti (2012) in Indonesia which showed that lack of trust in breastmilk production caused some mothers to give additional food and or other drinks to babies. However, partners who know the benefits of breastmilk to a baby's health want their teen mothers to breastfeed. In the present systematic review, all studies were conducted in the middle to high-income countries that the partners had a high understanding of the importance of breastfeeding that most partners provided positive breastfeeding information and support to teen mothers. 
Hence, it is supposed to be noticed that the research conducted by James et al. (2020) illustrates that not all information provided by families about breastfeeding is correct. Lack of informational coherence between teen mothers and their families may yield mental distress for these women because of informational differences received and believed. It requires breastfeeding enhancement from health care professionals to minimize unsolved breastfeeding issues.

\section{Limitation}

This study has limitations in the number of articles found and being reviewed. Very few articles discuss the types of family and partner support related to the success of breastfeeding among adolescent mothers. Even if there are articles available, there are still few that discuss in depth the forms of support and the role of families and partners regarding the success of breastfeeding carried out by adolescent mothers. Most of the findings show that there is support and there is a role of the family, but it is not explained in more detail what kind of support and role is needed by these women.

\section{Summary}

A systematic review has been carried out to contextualized; the extended family support given to adolescent mothers in achieving optimal breastfeeding. Successful breastfeeding occurs with the presence of family members as role models and motivators that build a positive self-image of adolescent mothers. The family also helps these women overcome difficulties to balance childbearing and schooling activities and financial hardship. This positive family support among adolescent women in the developed countries should be adopted by other women in developing countries to improve child health. Multidiscipline professionals, such as family nurses, midwives, pediatricians, psychologists, community leaders, teachers, and policymakers, should establish collaboration in manage the breastfeeding issues among young women that these women's educational and reproductive rights and needs are fulfilled. Thus, maternal and child health increases. Further research should be conducted to explore the family support for adolescent women in the developing world and develop breastfeeding programs that are sensitive to adolescent mothers' needs with their family's involvement.

\section{Key points}

- $\quad$ The success of breastfeeding is seen from the decision to breastfeed, early initiation of breastfeeding, the continuation of breastfeeding, and exclusive breastfeeding An adolescent breastfeeding mother is breastfeeding a baby when the mother is between 14 and 19 years old.

The support of the closest person is the support that is obtained from people who have blood ties to the teen mothers and the biological father of the baby.

- $\quad$ Family support in the form of appreciation support, instrumental support, emotional, and informational support is associated with successful breastfeeding in adolescent mothers.

\section{Contribution}

VP initiated the concept for the paper and search the related publication. All authors (VP, YA and DJ) have substantially contributed to the design, data extraction, analysis, and appraisal of the quality of these articles. The article was drafted by VP and all authors (VP, YA and DJ) revised for important content.

\section{References}

1. Ogbo FA, Eastwood J, Page A, Arora A, McKenzie A Jalaludin $B$, et al. Prevalence and determinants of cessation of exclusive breastfeeding in the early postnatal period in Sydney, Australia. Int Breastfeed J. 2017;12:16. https://doi.org/10.1186/ s13006-017-0110-4

PMid:28405212

2. de Oliveira LD, Giugliani ER, Santo LC, Nunes LM. Counselling sessions increased duration of exclusive breastfeeding: A randomized clinical trial with adolescent mothers and grandmothers. Nutr J. 2014;13(1):73. https://doi. org/10.1186/1475-2891-13-73

PMid:25033743

3. World Health Organization. Breastfeeding in The $21^{\text {st }}$ Century. Geneva: World Health Organization; 2016. Available from: https://www.who.int/pmnch/media/news/2016/breastfeeding_ brief.pdf. [Last accessed on 2021 Jul 12].

4. World Health Organization. Global Breastfeeding Scorecard, 2018: Enabling Women to Breastfee through Bettr Polisies and Programmes 2018 Date. Available from: Available from: https:// www.who.int/nutrition/publications/infantfeeding/global-bfscorecard-2018.pdf. [Last accessed on 2021 Jun 18].

5. Kanhadilok S, McGrath JM. An integrative review of factors influencing breastfeeding inadolescentmothers. JPerinatalEduc. 2015;24(2):119-27. https://doi.org/10.1891/1946-6560.24.2.119 PMid:26957895

6. Pillay S, Sibanda W, Ghuman MR, Coutsoudis A. Infant feeding practices of teenage mothers attending a well-baby clinic in a public hospital in Umlazi, KwaZulu-Natal, South Africa. South Afr J Clin Nutr. 2018;31(1):14-9. https://doi.org/10.1080/160706 58.2017.1338841

7. Muelbert M, Giugliani ER. Factors associated with the maintenance of breastfeeding for 6,12 , and 24 months in adolescent mothers. BMC Public Health. 2018;18(1):675. 
https://doi.org/10.1186/s12889-018-5585-4

PMid:29855364

8. Sipsma HL, Magriples U, Divney A, Gordon D, Gabzdyl E, Kershaw T. Breastfeeding behavior among adolescents: Initiation, duration, and exclusivity. J Adolesc Health. 2013;53(3):394-400. https://doi.org/10.1016/j.jadohealth.2013.04.005 PMid:23725911

9. Benova L, Siddiqi M, Abejirinde IO, Badejo O. Time trends and determinants of breastfeeding practices among adolescents and young women in Nigeria, 2003-2018. BMJ Global Health. 2020;5(8):e002516.

10. Wambach KA, Aaronson L, Breedlove G, Domian EW, Rojjanasrirat W, Yeh HW. A randomized controlled trial of breastfeeding support and education for adolescent mothers. Western J Nurs Res. 2011;33(4):486-505. https://doi. org/10.1177/0193945910380408 PMid:20876551

11. Grassley JS. Adolescent mothers' breastfeeding social support needs. J Obstetr Gynecol Neonatal Nurs. 2010;39(6):713-22. https://doi.org/10.1111/j.1552-6909.2010.01181.x PMid:20880051

12. UNFPA. Adolescent Pregancy; 2017 Date. Accessed. Available from: https://www.unfpa.org/adolescent-pregnancy. [Last accessed on $2021 \mathrm{Jul} 10]$

13. Nuampa S, Tilokskulchai F, Patil CL, Sinsuksai N, Phahuwatanakorn W. Factors related to exclusive breastfeeding in Thai adolescent mothers: Concept mapping approach. Maternal Child Nutr. 2019;15(2):e12714. https://doi.org/10.1111/ mcn.12714

PMid:30303630

14. Smith PH, Coley SL, Labbok MH, Cupito S, Nwokah E. Early breastfeeding experiences of adolescent mothers: A qualitative prospective study. Int Breastfeed J. 2012;7(1):13. https://doi. org/10.1186/1746-4358-7-13

PMid:23020833

15. de Lacerda AC, Lucena de Vasconcelos MG, Nascimento de Alencar E, Osório MM, Pontes CM. Adolescent fathers: Knowledge of and involvement in the breast feeding process in Brazil. Midwifery. 2014;30(3):338-44. https://doi.org/10.1016/j. midw.2013.01.006

PMid:23473910

16. Jara-Palacios MÁ, Cornejo AC, Peláez GA, Verdesoto $\mathrm{J}$, Galvis AA. Prevalence and determinants of exclusive breastfeeding among adolescent mothers from Quito, Ecuador: A cross-sectional study. Int Breastfeed J. 2015;10(1):1-8. https:// doi.org/10.1186/s13006-015-0058-1

PMid:26692888

17. Woods NK, Chesser AK, Wipperman J. Describing adolescent breastfeeding environments through focus groups in an urban community. J Prim Care Community Health. 2013;4(4):307-10. https://doi.org/10.1177/2150131913487380 PMid:23799673

18. Yılmaz E, Yılmaz Z, Isık H, Gultekın IB, Timur H, Kara F, et al. Factors associated with breastfeeding initiation and exclusive breastfeeding rates in Turkish adolescent mothers. Breastfeed Med. 2016;11(6):315-20. https://doi.org/10.1089/bfm.2016.0012 PMid:27183042

19. Theodorah DZ, Mc'Deline RN. The kind of support that matters to exclusive breastfeeding a qualitative study. BMC Pregnancy nd Childbirth. 2021;21(1):1-8. https://doi.org/10.1186/ s12884-021-03590-2

PMid:33563230

20. Gómez EP, Nariño CC, Rueda AG. Adolescent mothers a challenge facing the factors influencing exclusive breastfeeding/ Madres adolescentes, un reto frente a los factores que influyen en la lactancia materna exclusiva. Enferm Global. 2014;13(1):71-82.

21. Bootsri W, Taneepanichskul S. Effectiveness of experiential learning with empowerment strategies and social support from grandmothers on breastfeeding among Thai adolescent mothers. Int Breastfeed J. 2017;12(1):1-9.

22. Tong A, Flemming K, Mclnnes E, Oliver S, Craig J. Enhancing transparency in reporting the synthesis of qualitative research: ENTREQ. BMC Med Res Methodol. 2012;12(1):1-8.

23. Nelwati, Abdullah KL, Chan CM. Asystematic review of qualitative studies exploring peer learning experiences of undergraduate nursing students. Nurse Educ Today. 2018;71:185-92. https:// doi.org/10.1016/j.nedt.2018.09.018

PMid:30293048

24. Lucas R, Bernier K, Perry M, Evans H, Ramesh D, Young E, et al. Promoting self-management of breast and nipple pain in breastfeeding women: Protocol of a pilot randomized controlled trial. Res Nurs Health. 2019;42(3):176-88. https://doi. org/10.1002/nur.21938

PMid:30835887

25. Critical Appraisal Skills Programme (CASP) Systematic Review Checklist; 2019. Available from: https://www.casp-uk.net. [Last accessed on 2021 Apr 25].

26. Kanavaki AM, Rushton A, Klocke R, Abhishek A, Duda JL. Barriers and facilitators to physical activity in people with hip or knee osteoarthritis: Protocol for a systematic review of qualitative evidence. BMJ Open. 2016;6(11):e012049. https:// doi.org/10.1136/bmjopen-2016-012049

PMid:27810971

27. Thomas J, Harden A. Methods for the thematic synthesis of qualitative research in systematic reviews. BMC Med Res Methodol. 2008;8(1):45. https://doi.org/10.1186/1471-2288-8-45

28. Dykes F, Moran VH, Burt S, Edwards J. Adolescent mothers and breastfeeding: Experiences and support needs-an exploratory study. J Hum Lact. 2003;19(4):391-401. https://doi. org/10.1177/0890334403257562 PMid:14620453

29. Acheampong AK. Perceived enablers of exclusive breastfeeding by teenage mothers in Ghana. South Afr Fam Pract. 2020;62(1):1-5. https://doi.org/10.4102/safp.v62i1.5108 PMid:33054255

30. Nesbitt SA, Campbell KA, Jack SM, Robinson H, Piehl K, Bogdan JC. Canadian adolescent mothers' perceptions of influences on breastfeeding decisions: A qualitative descriptive study. BMC Pregnancy Childbirth. 2012;12(1):1-14.

31. Wambach KA, Cohen SM. Breastfeeding experiences of urban adolescent mothers. J Pediatr Nurs. 2009;24(4):244-54. https:// doi.org/10.1016/j.pedn.2008.03.002

PMid:19632502

32. Hannon PR, Willis SK, Bishop-Townsend V, Martinez IM, Scrimshaw SC. African-American and Latina adolescent mothers' infant feeding decisions and breastfeeding practices: A qualitative study. J Adolesc Health. 2000;26(6):399-407. https://doi.org/10.1016/s1054-139x(99)00076-2

PMid: 10822181

33. Nelson A, Sethi S. The breastfeeding experiences of Canadian teenage mothers. J Obstet Gynecol Neonatal Nurs. 2005;34(5):615-24. https://doi.org/10.1177/0884217505280279 PMid: 16227517

34. Nuampa S, Tilokskulchai $F$, Sinsuksai N, Patil CL, Phahuwatanakorn W. Breastfeeding experiences among Thai adolescent mothers: A descriptive qualitative study. Pac Rim Int J Nurs Res. 2018;22(4):288-303.

35. Sriyasak A, Åkerlind I, Akhavan S. Childrearing among Thai first-time teenage mothers. J Perinat Educ. 2013;22(4):201-11. 
https://doi.org/10.1891/1058-1243.22.4.201

PMid:24868133

36. Clark C, Kimberly P. Exploring the role of social support in understanding barriers to breastfeeding practices for adolescent mothers in Western North Carolina: A preliminary study. Int Public Health J. 2018;10(3):333-42.

37. Emmott EH, Mace R. Practical support from fathers and grandmothers is associated with lower levels of breastfeeding in the UK millennium cohort study. PLoS One. 2015;10(7):e0133547. https://doi.org/10.1371/journal. pone.0133547

PMid:26192993

38. Brown A, Raynor P, Lee M. Young mothers who choose to breast feed: The importance of being part of a supportive breast-feeding community. Midwifery. 2011;27(1):53-9. https:// doi.org/10.1016/j.midw.2009.09.004

PMid:19896254

39. Nuampa S, Chanprapaph P, Tilokskulchai F, Sudphet M Breastfeeding challenges among Thai adolescent mothers: Hidden breastfeeding discontinuation experiences. J Health Res. 2020. https://doi.org/10.1108/JHR-01-2020-0011

40. Monteiro JC, Dias FA, Stefanello J, Reis MC, Nakano AM, Gomes-Sponholz FA. Breast feeding among Brazilian adolescents: Practice and needs. Midwifery. 2014;30(3):359-63. https://doi.org/10.1016/j.midw.2013.03.008 PMid:23652288

41. Khonsung $P$, Yimyam $S$, Xuto $P$, Chaloumsuk N. Factors predicting exclusive breastfeeding among Thai adolescent mothers at 6-months postpartum. Pac Rim Int $\mathrm{J}$ Nurs Res. 2021;25(1):34-47. 